University of Pennsylvania ScholarlyCommons

GSE Publications

Graduate School of Education

1994

\title{
Organizational Control in Secondary Schools
}

Richard Ingersoll

University of Pennsylvania, rmi@upenn.edu

Follow this and additional works at: https://repository.upenn.edu/gse_pubs

Part of the Education Commons

\section{Recommended Citation}

Ingersoll, R. (1994). Organizational Control in Secondary Schools. Harvard Educational Review, 64 (2), 150-173. http://dx.doi.org/ 10.17763/haer.64.2.x8j1h41012261666

This paper is posted at ScholarlyCommons. https://repository.upenn.edu/gse_pubs/542

For more information, please contact repository@pobox.upenn.edu. 


\title{
Organizational Control in Secondary Schools
}

\begin{abstract}
In educational research and policy, there are two viewpoints on organizational control in secondary schools: one, that schools are highly decentralized organizations in which teachers have workplace autonomy and discretion; two, that schools are top-down bureaucracies in which teachers have little influence over school operations. Both of these perspectives show substantial empirical support, but there has been little effort to explain the simultaneous presence of these contradictory images. Richard Ingersoll argues in this article that these two images derive from implicit differences in their emphases and in their assumptions concerning how to assess organizational control in schools. In order to empirically ground the debate and offer a more elaborated and refined view of the issues, Ingersoll presents an analysis of data from the 1987-1988 Schools and Staffing Survey conducted by the National Center for Education Statistics. He examines who controls key social, sorting, and behavioral activities and decisions occurring in schools, comparing the control reportedly exercised by faculties with that exercised by principals and central boards across different types of schools.
\end{abstract}

\section{Disciplines}

Education 


\section{POST-PRINT VERSION}

The following is the authorized publisher PDF of the article, after editing and typesetting, published as:

"Organizational Control in Secondary Schools"

By RICHARD M. INGERSOLL

Harvard Educational Review, vol. 64:2 (Summer 1994) pp. 150-173

https://doi.org/10.17763/haer.64.2.x8j1h41012261666

https://www.hepgjournals.org/doi/abs/10.17763/haer.64.2.x8j1h41012261666?=

This copy is intended for non-commercial research and educational use, including for instruction at the author's institution and sharing with colleagues, as well as for archiving purposes. All other uses, such as reproduction and distribution, or selling or licensing copies, or posting to third party websites, are prohibited. For further information, or for permission to reprint or to purchase copies of the final published version of the article, please contact Harvard Education Publishing Group (HEPG) at hepg@ @arvard.edu, or 617-495-3432.

The Harvard Educational Review (ISSN 0017-8055) is a scholarly journal of opinion and research in education. Its mission is to provide an interdisciplinary forum for discussion and debate about education's most vital issues. Since its founding in 1930, the Review has become a widely recognized journal in education, with circulation to policymakers, researchers, administrators, and teachers. The Review is published by Harvard Education Publishing Group.

Contact HEPG at:

8 Story Street, 1st Floor

Cambridge, MA 02138

$617-495-3432 \mathrm{ph}$

617-496-3584 fax

hepg@ harvard.edu

http://www.harvardeducationalreview.org

Thank you. 


\section{Organizational Control in Secondary Schools}

RICHARD M. INGERSOLL

American Institutes for Research, Washington, DC

In educational research and policy, there are two viewpoints on organizational control in secondary schools: one, that schools are highly decentralized organizations in which teachers have workplace autonomy and discretion; two, that schools are top-down bureaucracies in which teachers have little influence over school operations. Both of these perspectives show substantial empirical support, but there has been little effort to explain the simultaneous presence of these contradictory images. Richard Ingersoll argues in this article that these two images derive from implicit differences in their emphases and in their assumptions concerning how to assess organizational control in schools. In order to empirically ground the debate and offer a more elaborated and refined view of the issues, Ingersoll presents an analysis of data from the 1987-1988 Schools and Staffing Survey conducted by the National Center for Education Statistics. He examines who controls key social, sorting, and behavioral activities and decisions occurring in schools, comparing the control reportedly exercised by faculties with that exercised by principals and central boards across different types of schools.

Over the past decade, both educational researchers and policymakers have increasingly focused on the degree of organizational control over teachers and their work in schools. For researchers, a continuing interest in the nature and impact of schools, as opposed to the characteristics of students or staffs, has led to increasing attention to the organizational structure of schools and, in particular, to the degree of administrative control or faculty autonomy found in schools. For policymakers, the growing national interest in site-based management, school choice, and educational restructuring has led to increasing attention to the nature and consequences of decisionmaking and management within schools.

Although the subject of organizational control in schools has become of great interest and importance, it is marked by substantial disagreement over the degree to which schools and teachers are controlled. This article examines the two

Harvard Educational Review Vol. 64 No. 2 Summer 1994

Copyright $(\odot$ by President and Fellows of Harvard College $0017-8055 / 94 / 0500-150 \$ 1.25 / 0$ 
most prominent and contradictory viewpoints on organizational control in schools.

Traditionally, studies of both teachers' working conditions and the organizational structure of schools have found schools to be an unusual type of modern organization and teaching an unusual type of occupation. Schools, researchers have argued, exhibit an exceptional degree of "structural looseness" compared to most organizations, because of the incompatibility between educating children and formal bureaucratization (Bidwell, 1965; Dreeben, 1973; Lortie, 1969, 1975). Among those who study occupations, work, and organizations in general, this theme has been reformulated and made the core of one of the more prominent contemporary perspectives within this interdisciplinary field. This perspective focuses on organizations characterized by an inordinate lack of coordination, control, consensus, and accountability. Researchers have created a colorful vocabulary to describe these settings, maintaining that schools are the archetype of such "loosely coupled systems" and "organized anarchies" (Cohen, March, \& Olsen 1972; March \& Olsen, 1976; Meyer \& Scott, 1983; Weick, 1976, 1984).

As a result, until very recently, the conventional wisdom among both organizational and educational researchers has been that schools are highly decentralized organizations, and that teaching, although in many ways not a self-regulating profession, is characterized by a great deal of workplace autonomy and discretion (Firestone, 1985; Stevenson \& Baker, 1991; Tyler, 1988).

Beginning in the early $1980 \mathrm{~s}$, the subject of school organization and management became of increasing importance in a second arena - that of educational policy and reform. While the research community differed over the implications of loose structuring for school and teacher performance, those participating in the policy and reform debate tended, initially, to assume that a lack of coordination and control in schools has been a major factor in the educational crisis. A number of national studies and reports concluded that school problems are, to an important extent, a result of inadequacies in the classroom performance of teachers. The target of scrutiny and, ultimately, blame from this perspective was typically the ability, the training, or the motivation of individual teachers. Successful reform, these critics have argued, must, therefore, focus on greater accountability, higher standards, top-down state controls, national goals, and a general "tightening of the ship" (Bacharach, 1990; Goodlad, 1985; Kirst 1989; National Commission on Excellence in Education, 1983; Weis, Altbach, Kelly, Petrie, \& Slaughter, 1989; Wise, 1979).

There is, however, a second view of school organization, which is antithetical to the traditional "loose-schools" perspective. This viewpoint is also perennially popular, but among a different group of education reformers, policymakers, and researchers. Schools are not too decentralized, those in this group hold, but exactly the opposite. They argue that highly bureaucratized school systems have become stultifying, rigid, and unresponsive, and that schools have become the epitome of the modern centralized undemocratic bureaucracy (Conley \& Cooper, 1991; Sergiovanni \& Moore, 1989).

More than one version of this anti-bureaucracy viewpoint has appeared. One version concentrates on community and client control and makes the argument 
that local constituencies and parents do not have adequate input into their children's and communities' schools. As Katz (1972) suggested over twenty years ago, this theme resurfaces on a regular basis in U.S. education. For instance, in the late 1960 s and early 1970s, numerous reform groups sought to reform schools by implementing community control (Borman \& Spring, 1984; Fantini, Gittell, \& Magat, 1979; Ravitch, 1974; Rogers, 1968) or by institutionalizing increased student input into school affairs (Kozol, 1967). More recently, advocates of school "choice" reforms have adopted the same arguments and rhetoric that is, that powerful central school boards deny parents any voice in their children's education. Ironically, this version of school decentralization often advocates reform measures similar to those offered by the traditional loose-schools viewpoint. For instance, the objective of much of the choice movement is often to increase the accountability of schools and teachers by shifting substantial control from school staffs to parents and communities (Clune \& Witte, 1990).

Nevertheless, community control is often confused with a different and newer version of the anti-bureaucracy viewpoint. Over the past several years, reformers and researchers alike have extended and applied this critique specifically to the working conditions of teachers. The focus of this group is the impact of the bureaucratic structure of schools on teachers and teaching. In this view, public schools in particular are far too often based on an archaic nineteenth-century factory model of organization. Such schools, they argue, unduly disempower, de-professionalize, and de-motivate teachers. Hence, in this view, schools and teachers are already overly controlled and overly constrained - a situation that is both dissatisfying to teachers and a source of school inefficiency and ineffectiveness (Bacharach, Bauer, \& Shedd, 1988; Corcoran, Walker, \& White, 1988; Johnson, 1990; Rosenholtz, 1989; Shedd \& Bacharach, 1991). Typically, this viewpoint advocates forms of decentralization, such as school-based management, that are designed to increase the authority, autonomy, and professionalism of teachers (Carnegie Forum, 1986; Holmes Group, 1986; Weis et al., 1989).

As a result of these changes in both the policy and research realms, there is now considerable debate over the degree to which teachers are subject to organizational control. Underlying much of this debate are contradictory images of the manner in which schools are organized. The traditional loose-schools perspective portrays schools as organized anarchies and finds school faculties to be overly autonomous and to lack sufficient accountability. The newer disempowerment perspective portrays schools as top-down bureaucracies and finds school faculties to lack sufficient influence over school operations. Both of these perspectives show substantial empirical support, offer policy agendas, and have fostered numerous reform measures. But, although many have drawn attention to the dissimilarity of these two polar perspectives (see, for example, Kirst, 1989; Rowan, 1990), there has been little effort to explain the simultaneous presence of contradictory images of organizational control in schools, and little effort to test empirically which viewpoint is more valid.

In this article, I address this contradiction by empirically examining nationally representative data on the levels, distribution, and variations of organizational 
control, centralization, and decentralization in secondary schools. The data come from the 1987-1988 Schools and Staffing Survey (SASS), a nationally representative survey of school teachers and administrators conducted by the National Center for Education Statistics (NCES), the statistical agency of the U.S. Department of Education.

The major argument of this article is that assessing control in schools depends on the issues examined, the valuative criteria used, the level of analysis chosen, and the schools investigated. I show that the differing conclusions of each of the two contradictory viewpoints largely derive from implicit differences in their emphases and in their assumptions concerning how to assess organizational control in schools. My objective is to empirically ground the debate and offer a more elaborated and refined view of organizational control in schools. This investigation draws particular attention to a neglected but important dimension - that is, who controls the key social, sorting, and behavioral activities and decisions occurring within schools.

After examining differences in the influence and control exercised by teachers over different sets of activities within schools, the analysis proceeds to the question of evaluating these levels of control and assessing the extent to which schools are or are not decentralized or centralized organizations. To do so, I directly compare the control reportedly exercised by faculties with that exercised by both principals and central boards over key activities within schools.

Finally, the analysis turns to an examination of the extent to which control varies among different kinds of schools. I specifically address the question: In what types of schools do faculty have the greatest and the least say and what proportion of the teaching force works in each of these different types of schools?

\section{Data and Methods}

The Schools and Staffing Survey is one of the largest and most comprehensive data sources available on the organizational structure and character of schools. This survey was conducted to remedy the lack of nationally representative data on the staffing, occupational, and organizational characteristics of schools. ${ }^{1}$ The U.S. Census Bureau collected the data for NCES in 1988 from a random sample, stratified by state, sector, and school level. The survey consisted of separate questionnaires for the principals of the schools sampled, for administrators of the central school or governing board of each sample school, and for faculty within each sample school. Within each school, from three to twenty teachers (average of four) were randomly sampled, depending on level, size, and sector of the school. The response rate was quite high: 86 percent for public school

\footnotetext{
I SASS data tapes, survey questionnaires, and user's manuals are available from NCES, U.S. Department of Education, 555 New Jersey Ave., Washington, DC 20208-5641. For information concerning the survey design and sample estimation of SASS, see Kaufman (1991). For an extensive report that summarizes the items used in this investigation and provides an overview of the entire survey, see Schools and Staffing in the U.S.: A Statistical Profile, 1987-88 (Choy, Medrich, Henke, \& Bobbitt, 1992).
} 
teachers; 79 percent for private school teachers; 94 percent for public school administrators; and 79 percent for private school administrators. All the data reported here are weighted to be representative of the national population of teachers and schools in $1988 .^{2}$

This analysis focuses on secondary schools serving grades seven through twelve, including both junior and senior high schools. The sample contains 24,480 teachers and principals from 5,292 schools. Approximately 17 percent of the school sample (889) is in the private sector. Because private schools are usually smaller than public schools, approximately 9 percent of these teachers $(2,158)$ are employed in the private sector.

In the debate over school organization, different analysts and observers have focused on a wide variety of different units of analysis (e.g., students, parents, teachers, administrators, school boards, state agencies) and different levels of analysis (e.g., classrooms, schools, districts, states).

The topic, however, that lies at the crux of the debate as to whether schools are organizationally centralized or decentralized, and that provides the focus of this investigation, is the relative degree of control exercised by faculty and administrators over school activities and decisions. Therefore, the units of analysis in this study are schools rather than individuals in schools. The data represent either school-level responses, as in the case of information collected from administrators, or school-wide averages, as in the case of information collected from teachers. Aggregating individual-level data in the latter case, of course, underemphasizes diversity within schools, but it allows the empirical analysis to narrow its focus to the topic of interest - the levels, distribution, and variations of organizational control. ${ }^{3}$

${ }^{2}$ Throughout, this analysis uses data weighted to compensate for the over- and under-sampling resulting from the complex, stratified survey design. Each observation is weighted by the inverse of its probability of selection in order to obtain unbiased estimates of population parameters.

${ }^{3}$ The data used in this investigation are multi-level. They represent responses collected from both individual teachers within schools and from administrators of those schools. There has been a great deal of debate concerning the appropriate level of analysis for such data (e.g., Bidwell \& Kasarda, 1980; Pfeffer, 1982; Rowan, Raudenbush, \& Kang, 1991). As a result, several multi-level statistical techniques and packages have been recently developed specifically to capitalize on the nested or hierarchical nature of such data (see, for example, Bryk \& Raudenbush, 1992).

Background analyses for this investigation using all three approaches (individual-, school-, and multi-level) indicate that there are not appreciable differences in their results for the questions addressed here. As a result, this investigation will be couched at a school level of analysis, because that level most closely matches the level of the research questions addressed. School-wide conditions are represented by both principals' reports and the means of teachers' reports for those schools. Teacher weights were used in aggregating the teacher scores. School weights were used in the analysis proper.

This investigation, however, does not assume that schools are uniform entities. As in many previous analyses of school organization (e.g., Lee, Dedrick, \& Smith, 1991; Pallas, 1988), diversity exists across teachers within schools for teachers' reports of organizational conditions, but these reports are only weakly related to commonly measured teacher characteristics (e.g., gender, race, experience, education, subject taught, salary). This suggests there is both actual variation in control among teachers within schools and also some degree of measurement error.

Background analysis also indicates substantial variation among schools for the items of interest here. This variation suggests that control is also a collective property of schools. The levels, distribution, and variations of this organizational control provide the focus of this investigation. 
Organizational Control

RICHARD M. INGERSOLL.

\section{Measures of Organizational Control in Schools}

Control is measured in this investigation by both teachers' and administrators' reports of their influence or control over a range of decisions and policies within schools.

The teacher questionnaire obtained data on teachers' influence or control over decisions and policies concerning nine important educational activities within schools. These questions focused on both teachers' influence over school policies, such as those concerned with curriculum and discipline, and their control over activities within classrooms, such as selecting teaching materials and methods. The questionnaire items used a six-point scale from "none" to "a great deal" or "complete control."

The principal questionnaire obtained data on the relative influence of central school administrative or governing boards, school principals (or headmasters in private schools), and teachers. School principals were asked to evaluate the influence of these groups over decisions and policies concerned with three key areas within schools: faculty hiring, establishing curriculum, and student discipline policy. As before, respondents evaluated these influence levels on a sixpoint scale from "none" to "a great deal."

Although respondents' reports of organizational characteristics, such as the distribution of control, are one of the most commonly used sources of information in organizational research, it is necessary to acknowledge several limitations inherent to such data. Researchers have long noted the difficulties in obtaining reliable and valid information about control and influence in organizations (Pfeffer, 1981). Most methods for assessing these phenomena in social settings are confronted with questions concerning both respondent candor and accuracy. The approach used here treats organization members as informants of conditions in their organizational settings. One of the advantages of this approach is that the information comes from those who most closely experience it. Because such data represent members' perceptions, however, these responses are, by definition, not objective assessments, but, rather, subjective attributions. Respondents may have different experiences and perspectives; hence, wide variation in their perceptions can be expected.

One means of addressing these limitations is by using data from a range of respondents representing different roles and perspectives in the organization. In this case, SASS provides data from both a random sample of teachers and from the principal of each school. Each group can be expected to have different perspectives on school characteristics, and neither perspective may be more valid in an absolute sense. Indeed, as the analysis to follow indicates, in the two instances in which both teachers and principals were asked the same question about teachers' influence over school curriculum and discipline, there is disagreement. On the other hand, there is consistency in the two sets of responses when compared across activities and across schools. This investigation will focus on these comparisons, and thus attempt to take advantage of the strengths of each group's point of view. For instance, because teachers are closer to the educational process itself, this analysis will use their reports to compare teacher 
control across different types of key educational and teaching activities. Principals, on the other hand, are further removed from the details of the educational process and more involved with overall organizational activities. Hence, their reports will be used to discern the relative influence exercised by different groups and the overall hierarchical distribution of control in schools. The analysis begins with an examination of teachers' reported control in schools.

\section{Teacher Control of the Educational Core}

Assessments of organizational control typically focus on two critical questions: First, what are the key processes and activities within an organization? Second, which groups or members control decisions and policies concerned with these activities?

Research on the organization of schools, whether representing the traditional loose-schools perspective or the newer disempowerment perspective, commonly subscribes to what has been labelled the "zone view" of school structure. In this view, school processes and activities are divided into separate classroom and school-wide zones (Lortie, 1969, 1975; Tyler 1988). The zone view of schools is an adaptation of the traditional core/structure framework commonly used by those who study work and organizations in general (Pfeffer, 1982). This framework subdivides organizations into a technical core - the site of productive activities - and an administrative structure - the site of managerial activities. In educational research, core and structure have been translated into classroom and school-wide zones, respectively. The technical or productive core of school organizations is deemed to lie in the classroom, defined as the site of teaching and educational activities. On the other hand, the administrative structure is labelled as the school-wide zone, defined as the site of managerial, coordination, planning, and resource allocation activities.

Where the two perspectives of school control differ is in deciding which is the most important zone and set of activities to emphasize. The traditional looseschools perspective typically emphasizes the educational or classroom zone. Hence, when these researchers analyze how centralized or decentralized schools are, they commonly focus on how much influence and autonomy teachers have, or alternatively, how much control administrators have over educational matters within classrooms. They find that teachers have high levels of discretion over issues of classroom instruction and, typically, conclude that teachers are autonomous and schools decentralized (Firestone, 1985; Lortie, 1975; Meyer \& Scott, 1983).

The newer disempowerment perspective, on the other hand, does not deny that teachers have substantial autonomy over issues of classroom instruction. Those who hold this point of view instead draw attention to the importance of the school-wide zone. They hold that teachers ought to have input into a school's allocation, planning, and strategic policies. Hence, when analyzing how centralized or decentralized schools are, they commonly ask how much say faculties have or, alternatively, how much influence administrators have over important 
school-wide policies. They find little faculty influence and much administrative discretion over policy, resource allocation, and planning; hence, they have concluded that schools are overly centralized (Bacharach et al., 1988; Conley \& Cooper, 1991; Rosenholtz 1989; Shedd \& Bacharach, 1991).

The different conclusions of the two groups of researchers partly result from their different emphases. Each draws attention to different types of activities and different levels of analysis. But, notably, both agree on the existing division of labor and control within schools: "Schools are marked by a "traditional influence pattern' in which decisions are differentiated by locale and position. . . Administrators make strategic decisions outside of classrooms and teachers make operational decisions inside of classrooms" (Conley, 1991, pp. 237-238).

Moreover, and central to the point, both groups of researchers accept a narrow view of the educational or productive core of schools. When it comes to operationalizing the latter concept, most researchers assume that the most fundamental educational processes are limited to the classroom and most emphasize academic instruction. This focus, however, underemphasizes some of the most important educational activities that occur within classrooms and across schools.

Beginning with classic education theory (Dewey, 1902/1974; Durkheim, 1925/1961; Sorokin, 1927; Waller, 1932), continuing through Parsons (1959) and related educational researchers (e.g., Dreeben, 1968; Henry, 1965; Jackson, 1968), and including more recent revisionist and critical analysts of schools (Apple, 1982; Bourdieu \& Passeron, 1977; Bowles \& Gintis, 1976; Giroux, 1982), investigators have long held that the major purpose of educational organizations lies in their social and institutional functions. Moreover, some have argued that this social role is expanding, as schools are being increasingly called upon to accept tasks once solely reserved for parents, churches, and communities (Coleman \& Hoffer, 1987). Current research on effective schools, for instance, has concluded that one of the most important indicators of the successful school is the presence and transmission of a "shared moral order" (Bryk, Lee, \& Smith, 1990; Grant, 1988; Kirst, 1989).

According to this view, the most important task of schools is the production of citizens and the reproduction of social order. This task involves two overlapping activities - socialization and sorting. The first involves the inculcation of societal norms, beliefs, behaviors, and roles. The second involves differentiation or the reproduction of societal patterns of stratification. This line of education theory draws attention to the idea that what students learn in schools is governed as much by school social relations as by the content of the official curriculum. Much of this social dimension is implicit, informal, and unstated, prompting observers often to use the term "hidden curriculum" (Giroux, 1982) to refer to the norms, values, and behaviors transmitted to students.

Despite this larger theoretical context, however, much empirical research in education, including that concerned with school control, adopts a far narrower focus - classroom academic instruction and, by extension, student academic performance, as measured on mass-produced standardized tests. Academic in- 
struction and achievement are, of course, integrally related to the socialization and sorting processes in schools. Because of this emphasis on academic instructional activities, however, researchers usually have not directly specified, nor examined, the behavioral and normative dimensions of school educational processes. As a result, these social activities have secondary empirical status.

For example, research on school control invariably focuses on the degree of teacher autonomy or administrative control over key instructional decisions, such as the selection of course textbooks and materials, the choice of classroom curricular topics, and the determination of teaching methods used in classrooms. In contrast, such research rarely focuses on who controls key socialization and sorting decisions. Researchers typically underemphasize the extent to which teachers shape the criteria by which students are tracked into ability groups, or the extent to which teachers have input into whether the school even uses tracking in the first place - one of the most fundamental social decisions schools face. Likewise, there has been little emphasis on the extent to which teachers influence or control their school's boundaries of permissible student behavior for issues such as student attendance, smoking, language use, evaluation, and expulsion.

Examination of the area of student discipline is one of the more glaring omissions in research on school control. Decisions concerning student discipline are among the most fundamental in schools. In the first place, without the maintenance of some degree of discipline and order, educational processes cannot proceed at all. Yet, student discipline is not simply a necessary prerequisite for the adequate enactment of instructional activities: Discipline is, at heart, an issue concerning which and whose set of norms are to dominate school life. Typically, discipline involves conflict between competing behavioral and moral codes, which often revolve around issues of class and race (Apple, 1982; Bowles \& Gintis, 1976; Giroux, 1982; Grant, 1988). Research on school control should ask the crucial question, who makes the decisions concerned with disciplinary aspects of the social order in schools?

In order to offer both a broader and more elaborated view of the organizational control of key educational processes in schools, the analysis below will examine the degree to which teachers exercise control over important educational activities, both in classrooms and school-wide, and will distinguish how these levels of control vary across both the social and instructional dimensions of the educational core.

There are, of course, a wide array of activities that could be included under the rubric of these core dimensions. SASS provides measures of a selected set of key activities representing each dimension. The social dimension is represented by decisions concerned with setting and enforcing norms and rules for student behavior, selecting criteria and means for tracking students, and determining programs for socializing and standardizing teacher behavior. Representing the instructional dimension are decisions concerned with designing, establishing, and implementing the curriculum. 
TABLE 1

Percentage of Schools in Which, on Average, Teachers Report Having a Great Deal of Influence or Complete Control over Selected Activities

\begin{tabular}{lc}
\hline Activities & $\begin{array}{c}\text { Percentage } \\
(n=5,292)\end{array}$ \\
\hline Social Dimension & 8 \\
Setting school policy on grouping students in classes by ability & 8 \\
Determining faculty in-service programs & 11 \\
Determining school discipline policy & 42 \\
Disciplining students in classrooms & 17 \\
Mean Percentage for Social Dimension & \\
\hline Instructional Dimension & 15 \\
Establishing school curriculum & 44 \\
Selecting classroom texts and materials & 51 \\
Selecting classroom content and topics & 80 \\
Selecting classroom teaching techniques & 85 \\
Determining classroom homework levels & 55 \\
Mean Percentage for Instructional Dimension &
\end{tabular}

Note: Teachers are defined as having a "great deal of influence" or "complete control" if the school's mean score was greater than five on a scale of one to six.

Table 1 displays the percentage of schools in which teachers, on average, reported themselves to have substantial influence or control over the decisions or policies listed.

Several features are readily apparent from this table. First, the conventional zone view initially appears to be correct in that teachers report substantial influence over a number of instructional activities. It is also clear, however, that teachers' levels of control vary widely and that these variations depend on the dimension examined. In contrast, fewer school faculties report having substantial influence over either shaping the tracking policy, determining discipline policy for students, or making faculty in-service training decisions - all social functions. ${ }^{4}$

Moreover, there is a clear difference between teachers' control within classrooms and teachers' control over school policies. Teachers report far higher

${ }^{4}$ In-service programs - that is, in-school development and training programs for faculty - are examples of school activities that can be classified in more than one manner. Here, $I$ have classified in-service as a social issue because many such programs are designed as a means to socialize and standardize teacher behavior (Rowan, 1990). Indeed, researchers have traditionally assigned great importance to the role of teacher training in the normative control of teachers (e.g., Lortie, 1975). 
levels of control at the classroom level. Indeed, it is only in reference to instruction within classrooms, the traditional focus of much research, that a majority of school faculties report substantial control.

Even in this already delimited area of teacher control, however, there are other sources of constraint, which are overlooked in most analyses of organizational control in schools. Traditional research on school control has argued that, regardless of overall school curriculum policy, teachers are able, in reality, to exercise wide latitude and discretion over the curriculum within their classrooms. In this view, the decoupling of administrative structure and technical core results in teacher control over educational processes: that is to say, "behind the closed doors of their classrooms," teachers largely teach what they choose.

This view, however, overlooks the network of power relations that exist between teachers in classrooms and administrators in schools. Decisions concerned with classroom activities are neither independent of, nor of equal import to, decisions concerned with school policies. In extensive fieldwork associated with this research, I have found the classroom and administrative zones to be highly connected, not loosely coupled (Ingersoll, 1993, forthcoming). For instance, in most schools, a number of classroom instructional decisions are, as indicated in Table 1, commonly delegated to teachers. These decisions, however, are often subsidiary to, largely nested within, and predetermined by higher order decisions not under the control of teachers. Typically, teachers are delegated responsibility for implementation, execution, and enforcement, but do not exercise actual control over the conception and determination of larger policies and decisions. The parameters of teachers' classroom activities are effectively set by larger school policies - standardized curricula, tracking criteria, testing programs, attendance requirements, evaluation procedures, student behavioral rules, disciplinary infraction codes, and teacher workplace rules. Hence, even in the domain of apparent teacher control - classroom instruction - teachers' choices and discretion are far more circumscribed than has been acknowledged in much research on school organization.

\section{The Hierarchical Distribution of Control}

Establishing the set of activities within schools upon which to focus, and determining levels of faculty influence over them, are necessary first steps in assessing organizational control in schools. However, it is also necessary to evaluate these levels. That is, what constitutes high or low levels of teacher control? On what basis is a setting labelled as centralized or decentralized? Organizational control, it must be remembered, is a relative concept, and the researchers must always pose the question, "Compared to what?" Close examination of the research on organizational control in schools reveals that each of the two polar perspectives, the loose-schools view and the new disempowerment view, assumes a very different standard of comparison.

The traditional perspective compares schools to the rational-bureaucratic ideal of organization, often known as the machine model of organization. In 
Organizational Control

RICHARD M. INGERSOLL

FIGURE 1

The Comparison of Schools with Other Organizations

\begin{tabular}{ll}
\hline Type of Organization & Distribution of Control \\
\hline $\begin{array}{l}\text { Traditional Loose-Schools Perspective } \\
\text { Rational Bureaucracy }\end{array}$ & Centralized \\
Educational Bureaucracy & Decentralized \\
New Disempowerment Perspective & \\
Professional Organization & Decentralized \\
Educational Bureaucracy & Centralized \\
\hline
\end{tabular}

comparison to this ideal, schools are found to be highly decentralized (Conley, 1991; Meyer \& Scott, 1983). In contrast, the newer disempowerment view commonly compares schools to a different standard - the ideal of the professional organization. This second standard is also a traditional ideal, but one that is, in important ways, diametrically opposite to the rational-bureaucratic model. While the bureaucratic machine model is synonymous with centralized control, the professional model of organization is synonymous with decentralization (Friedson, 1973; Pfeffer, 1982; Rowan, 1990). Hence, it is not surprising that the disempowerment viewpoint comes to a quite different conclusion from that of the loose-schools viewpoint - that is, that schools are highly centralized (Bacharach et al., 1988; Rosenholtz, 1989; Shedd \& Bacharach, 1991; see Figure 1).

Given their different standards of comparison, both viewpoints may well be correct. However, actually empirically testing either of these comparisons is difficult. In fact, school researchers rarely do so - their comparisons are largely based on hypothetical ideals of bureaucratic or professionalized workplaces (Conley, 1991; Meyer \& Scott, 1983). However, mere assertions that organizations are overly centralized or decentralized are scarcely sufficient. The analysis below offers one means of empirically testing these comparisons.

A closer look reveals that the relative influence of employees and management lies at the heart of the concepts of organizational control, centralization, and decentralization. Indeed, one of the key criteria distinguishing professions from other kinds of work, and the bureaucratic model from the professional model of organization, is the distribution of control between these two groups (Friedson, 1973, 1984). In other words, a key distinction in any organization is whether decisions concerned with technical and production processes are controlled from the administrative center, or whether these are delegated to employees and, hence, are decentralized. We would expect employees to have far less control than management in rationalized, bureaucratized workplaces and, alternatively, we would expect employees to have influence approaching that of management in decentralized, debureaucratized, or professionalized settings. Therefore, for evaluating a school's organization, a key question is: Which group 
TABLE 2

Percentage of Schools in Which Principals Report that Faculties, Boards, or Principals Have a Great Deal of Influence over Selected Activities

\begin{tabular}{lc}
\hline Activities & $\begin{array}{c}\text { Percentage } \\
(n=5,292)\end{array}$ \\
\hline Hiring New Full-Time Teachers & 2 \\
$\quad$ Faculties & 27 \\
Boards & 57 \\
Principals & \\
Setting School Discipline Policy & 18 \\
Faculties & 31 \\
Boards & 52 \\
Principals & \\
Establishing School Curriculum & 23 \\
Faculties & 24 \\
Boards & 31 \\
Principals & \\
Overall Mean Percentage for 3 Activities & 14 \\
Faculties & 27 \\
Boards & 47 \\
Principals & \\
\hline
\end{tabular}

Note: A score of six on a scale from one to six equals "a great deal of influence."

has more influence over important core educational activities, administrators or faculty? In other words, is there a hierarchical distribution of control within schools?

It is possible to provide an answer to this question by turning to the SASS data on the relative control of school central boards, school principals, and school faculties. Table 2 displays the percentage of schools in which principals reported each group, including themselves, to have a great deal of influence. The survey focused on a selected set of three key activities, which represent the instructional and social dimensions of the educational core and the administrative zone.

The results present a picture of intraorganizational centralization in schools, at least from the viewpoint of principals. For each of these key activities within schools, principals lie at the top of the hierarchy. For these three important activities, principals clearly view themselves as the most powerful actors and teachers as the least powerful actors within schools.

Especially striking is the principal/faculty gap over control of decisions concerned with establishing school curricula. Although teachers are traditionally 
Organizational Control

RICHARD M. INGERSOLL

thought to exercise high levels of control over many aspects of school instruction, and although the data in Table 1 suggest that teachers themselves believe that this is true for several specific activities, principals report that teachers have relatively little control over the overall school curricular program. According to principals, less than a quarter of high school faculties have a great deal of actual influence over decisions concerning the establishment of the curriculum in their schools. Moreover, even though a comparison of Tables 1 and 2 indicates that principals report teachers to be more frequently empowered regarding the overall curriculum than teachers themselves do, principals nevertheless report teachers to be less frequently influential than themselves over these activities.

Hence, if we accept the comparison of teachers' and administrators' reports of control as a valid criterion of the degree of centralization or professionalization in schools, this analysis suggests that for several key sets of decisions concerned with both core and administrative activities, teachers are highly de-professionalized and schools highly centralized.

It is also clear, however, that this assessment depends on the level of analysis chosen. Changing the focus from the intraorganizational to the interorganizational level yields a very different picture. That is, if we focus on the interface between principals and central boards rather than on the interface between teachers and administrators, schools appear quite autonomous. Principals report more influence than their central boards for all three activities - suggesting interorganizational decentralization - a finding to which I will return later.

\section{Variations in Control among Schools}

In this investigation, I have argued that assessment of organizational control in schools depends on the activities examined and the valuative criteria used. In addition, the degree of control may also depend on the schools investigated. It is necessary to determine if the levels of control and of hierarchy we have assessed do truly represent general trends. In other words, are schools generally similar in terms of control, or do particular types of schools stand out?

Previous research suggests that there are, in fact, important differences in the organizational character and conditions of schools, and that these differences are related to the context of the school, its community setting, and the type of students enrolled (Anderson, 1982; Pallas, 1988; Rowan et al., 1991). Differences in public and private sectors, in particular, have been the focus of a number of investigations of school organization; most studies have concluded that private schools are far more decentralized than public schools (Chubb \& Moe, 1990).

Most of this research has been concerned with assessing the effects of school organization and control on school performance. However, there has been little analysis of the extent of differences in control among different types of schools, and of the proportion of schools as a whole that can be described as centralized or decentralized. The discussion below turns to these questions.

Analysis of the SASS data indicates that, consistent with much previous research, among the most significant predictors of school control are school sector 
TABLE 3

Percentage of Schools in Which, on Average, Teachers Report Having a Great Deal of Influence or Complete Control over Selected Activities

\begin{tabular}{|c|c|c|c|c|}
\hline \multirow[t]{2}{*}{ Activities } & \multicolumn{2}{|c|}{ Public Schools } & \multicolumn{2}{|c|}{ Private Schools } \\
\hline & $\begin{array}{c}\text { Larger } \\
(n=1,839)\end{array}$ & $\begin{array}{c}\text { Smaller } \\
(n=1,094)\end{array}$ & $\begin{array}{l}\text { Larger } \\
(n=114)\end{array}$ & $\begin{array}{l}\text { Smaller } \\
(n=459)\end{array}$ \\
\hline \multicolumn{5}{|l|}{ Social Dimension } \\
\hline $\begin{array}{l}\text { Setting school policy on } \\
\text { grouping students in classes } \\
\text { by ability }\end{array}$ & 1 & 7 & 17 & 25 \\
\hline $\begin{array}{l}\text { Determining faculty in-service } \\
\text { programs }\end{array}$ & 3 & 9 & 11 & 17 \\
\hline $\begin{array}{l}\text { Determining school discipline } \\
\text { policy }\end{array}$ & 3 & 13 & 9 & 32 \\
\hline $\begin{array}{l}\text { Disciplining students in } \\
\text { classrooms }\end{array}$ & 30 & 50 & 61 & 59 \\
\hline $\begin{array}{l}\text { Mean Percentage for } \\
\text { Social Dimension }\end{array}$ & 9 & 20 & 25 & 33 \\
\hline \multicolumn{5}{|l|}{ Instructional Dimension } \\
\hline $\begin{array}{l}\text { Establishing school } \\
\text { curriculum }\end{array}$ & 5 & 19 & 23 & 37 \\
\hline $\begin{array}{l}\text { Selecting classroom texts } \\
\text { and materials }\end{array}$ & 26 & 61 & 55 & 52 \\
\hline $\begin{array}{l}\text { Selecting classroom content } \\
\text { and topics }\end{array}$ & 34 & 63 & 67 & 64 \\
\hline $\begin{array}{l}\text { Selecting classroom teaching } \\
\text { techniques }\end{array}$ & 79 & 82 & 93 & 80 \\
\hline $\begin{array}{l}\text { Determining classroom } \\
\text { homework levels }\end{array}$ & 87 & 88 & 86 & 77 \\
\hline $\begin{array}{l}\text { Mean Percentage for } \\
\text { instructional Dimension }\end{array}$ & 46 & 63 & 65 & 62 \\
\hline
\end{tabular}

Note: Smaller school size for both private and public here refers to those schools with student enrollments of less than or equal to 350 . Larger school size refers to schools with student enrollments greater than 650. Data for schools with enroliments between 351 and 650 is not displayed. Teachers are defined as having a "great deal of influence" or "complete control" if the school's mean score was greater than five on a scale of one to six.

and school size (Choy, Medrich, Henke, \& Bobbitt, 1992). Tables 3 and 4 provide an illustration of these differences for both teacher control over the educational core and for school hierarchy. Each table presents a typology of organizational control in schools based upon both the public/private distinction and school enrollment. 
Organizational Control

RICHARD M. INGERSOLL

TABLE 4

Percentage of Schools in Which Principals Report that Faculties, Boards, or Principals Have a Great Deal of Influence over Selected Activities

\begin{tabular}{|c|c|c|c|c|}
\hline \multirow[t]{2}{*}{ Activities } & \multicolumn{2}{|c|}{ Public Schools } & \multicolumn{2}{|c|}{ Private Schools } \\
\hline & $\begin{array}{c}\text { Larger } \\
(n=1,839)\end{array}$ & $\begin{array}{c}\text { Smaller } \\
(n=1,094)\end{array}$ & $\begin{array}{l}\text { Larger } \\
(n=114)\end{array}$ & $\begin{array}{l}\text { Smaller } \\
(n=459)\end{array}$ \\
\hline \multicolumn{5}{|c|}{ Hiring New Full-Time Teachers } \\
\hline Faculties & 3 & 2 & 6 & 4 \\
\hline Boards & 29 & 30 & 5 & 17 \\
\hline Principals & 52 & 51 & 82 & 78 \\
\hline \multicolumn{5}{|c|}{ Setting School Discipline Policy } \\
\hline Faculties & 14 & 17 & 23 & 28 \\
\hline Boards & 37 & 30 & 12 & 17 \\
\hline Principals & 45 & 47 & 76 & 70 \\
\hline \multicolumn{5}{|c|}{ Establishing School Curriculum } \\
\hline Faculties & 17 & 22 & 38 & 32 \\
\hline Boards & 32 & 20 & 11 & 12 \\
\hline Principals & 21 & 29 & 63 & 57 \\
\hline \multicolumn{5}{|c|}{ Overall Mean Percentage for 3 Activities } \\
\hline Faculties & 11 & 14 & 22 & 21 \\
\hline Boards & 33 & 27 & 9 & 15 \\
\hline Principals & 39 & 42 & 74 & 68 \\
\hline
\end{tabular}

Note: Smaller school size for both private and public here refers to those schools with student enrollments of less than or equal to 350. Larger school size refers to schools with student enrollments greater than 650. Data for schools with enrollments between 351 and 650 is not displayed. A score of six on a scale from one to six equals "a great deal of influence."

On one end of the scale lie the larger, public secondary schools. These schools employ over half $(55 \%)$ of all secondary school teachers in the United States. On average, 24 percent of the students in these schools are from poor families (i.e., eligible for the Federal Free Lunch Program) and 27 percent are from minority families.

On the other end of the scale lie the smaller, private secondary schools. These schools employ only 5 percent of secondary school teachers in the United States. On average, 11 percent of the students in these schools are from poor families and 16 percent are from minority families.

As expected, Table 3 shows that reported teacher control of the educational core varies widely among the different types of schools. Moreover, within each school type, teachers report similarly wide differences in their control over the two dimensions of the educational core. 
Larger, public schools lie on the most centralized end of the scale. In almost half of these schools, teachers on average report having high control over decisions within the instructional dimension. On the other hand, teachers report having equivalent control over decisions in the social dimension in less than one-tenth of these schools.

Smaller, private secondary schools lie on the least centralized end of the scale. It is striking, however, that even in this elite group, while, on average, teachers in over two-thirds of the schools report having substantial control over instructional activities, teachers in only a third of the schools report substantial faculty control over the social dimension of the core.

Hence, across a wide range of schools, the degree of teacher control depends on the activities examined. As before, two different pictures of teacher control emerge, depending on whether one focuses on the instructional or social dimension of the educational core of schools - a distinction underemphasized in most research on school organization. Although there are wide differences in control among different types of schools, for the vast majority, including private schools, important social decisions are highly centralized.

Table 4 turns to differences in the hierarchical ranking reported by principals for teachers, principals, and boards across the different school types. Especially striking are the overall differences in the hierarchy between public and private schools. In the first place, far more private school principals perceive themselves to be highly influential than do public school principals. For instance, averaging over the three activities examined, over two-thirds of the principals in private schools view themselves as having a great deal of influence, versus less than half of public school principals.

The primary source of this difference between private and public sectors appears to be the relative influence of school governing boards. Not surprisingly, these groups are far more often reported to be influential in the public sector. This finding seems to be a zero-sum pattern, that is, a trade-off: principals are more often influential and boards less often influential in private than public schools.

Moreover, as in the data from the teacher survey, there are distinct public/private differences in reports of faculty influence. On average, almost a quarter of the private school respondents report their faculties to have high influence, in contrast to about one-sixth of public school respondents. But, notably, in both sectors, faculty are perceived to have substantial control less often than school principals. These results further erode the argument that private schools are decentralized. That is, although it is true that private school teachers are perceived to be more frequently influential than their public counterparts, they are still, nevertheless, less often influential than their principals.

In sum, just as in the data on teacher control of the educational core displayed in Table 3 , these results bring to light the overwhelming extent of school centralization and teacher deprofessionalization across the population of secondary schools. Although there are wide differences, the vast majority of schools, including private schools, are reported to have a high degree of internal organ- 
izational control for these key activities. But the data also highlight an important distinction noted earlier: assessments of control depend on the level of analysis examined. The results suggest that both public and private schools are centralized at the intraorganizational level, but that both are decentralized at the interorganizational level.

This distinction between the control exercised by teachers and that of both levels of administration clarifies an important issue underlying two different versions of the disempowerment viewpoint of school control and different models of site-based management and school decentralization: does the locus of disempowerment in schools lie with teachers, or with teachers and their principals alike? Or, alternatively, does the locus of administrative control lie with central school boards, or with building principals?

Research on public school control suggests two possible answers to these questions. One stream of research, which focuses on the intraorganizational level, argues that it is primarily teachers within public schools who lack control (Bacharach et al., 1988; Corcoran et al., 1988). Another version focuses on the interorganizational level, arguing that public schools lack autonomy and that their staffs - that is, principals and teachers alike - are constrained by overbearing school boards (Borman \& Spring, 1984; Chubb \& Moe, 1990; Rogers 1968).

The analysis here suggests that the latter view is oversimplified. To be sure, it is true that if we focus solely on the interface between principals and their governing boards, public schools are more often constrained by their boards than are private schools. Nevertheless, public school principals still perceive themselves to be in control more often than their boards. The one exception is control of curriculum in larger public schools. In other words, although school boards are more powerful in the public sector, principals do not report themselves to be the beleaguered, constrained, middle managers depicted in many popular accounts.

Moreover, if we focus on the intraorganizational level, it becomes clear that principals are far more often in control than their faculties, in both public and private schools. Hence, the data suggest that in the majority of schools in this country, the locus of disempowerment lies with teachers, and the locus of empowerment lies with building principals.

\section{Conclusion}

The issue of organizational control in schools has become a topic of great importance, but there is still significant disagreement over the degree to which schools and teachers are controlled. My argument has been that distinguishing the degree of control in schools depends on the activities focused upon, the valuative criteria used, the level of analysis chosen, and the schools investigated. I have shown that the differing conclusions of the current prominent and contradictory viewpoints of school control largely derive from implicit differences 
in their emphases, and in their assumptions concerning how to assess organizational control in schools. The objective of this investigation has been to ground the debate empirically and to offer a more elaborated and refined view of organizational control in schools by examining nationally representative data on organizational centralization and decentralization in secondary schools.

Such an approach has its limits. This analysis relies on respondents' perceptions of organizational control as recorded in survey questionnaires. These data provide neither a means of capturing the social organization of power and influence, nor the actual mechanisms whereby control operates in schools. On the other hand, statistical analysis of survey data on a broad range and large number of teachers and school sites allows us to make generalizations concerning broad patterns in the reported distribution of control in schools and to establish appropriate comparisons of control across schools. As a result, this analysis highlights several overlooked aspects of the overall levels, distribution, and variations of organizational control across a wide range of schools.

First, this investigation draws attention to the importance of the often overlooked, but crucial, social, behavioral, and tracking activities within the core of schools. The data suggest that it is for those activities that are most fundamentally social - where the educational process involves the transmission of values, behaviors, and norms - that schools exhibit the greatest degree of internal organizational control.

This finding has implications for current trends in educational reform. School restructuring and decentralization efforts, for example, usually focus on expanding teacher input into either instructional activities, such as curricular innovation, or into administrative activities, such as hiring and budget allocation (David, 1989). In contrast, reforms rarely focus on a similar expansion of teacher influence over the social functions of schools - one of the most telling sites of centralized control.

Second, this analysis draws attention to the importance of empirically testing evaluations of whether schools are/are not centralized bureaucracies, or are/are not professionalized settings. This investigation offers one empirical means of evaluating the degree of organizational control in schools - the comparison of teachers' and administrators' reported influence over decisions representing a range of key activities within schools. This criterion illuminates the extent to which teachers are deprofessionalized and, in contrast, principals are relatively influential actors.

Third, this investigation draws attention to the extent to which assessments of control depend on the level of analysis chosen. The results suggest that both public and private schools are centralized at the intraorganizational level, but that both are decentralized at the interorganizational level.

These findings also have implications for reform. School restructuring, sitebased management, and decentralization efforts often confound teacher empowerment and principal empowerment. Is it teachers, principals, or school staffs as a whole that need to be empowered? The data suggest that these three options need to be carefully distinguished. 
Finally, this analysis draws attention to the degree to which organizational control varies across different kinds of schools. Larger public schools are frequently characterized by lower levels of reported teacher control than smaller private schools. Even in this latter group, however, faculty are infrequently reported by either themselves or by their principals to have substantial control over crucial social decisions. The data suggest that private schools are, in important ways, not particularly decentralized or professionalized settings, in contrast to much current thinking.

This finding also has implications for reform. For instance, school choice reforms often hold up private schools as examples to be emulated by public schools. Given private schools' relatively lower salary levels, relatively higher teacher turnover rates (Choy et al., 1992), and, as this analysis shows, high levels of internal organizational control, it may be premature to assume these are sites of superior teaching conditions.

In sum, the objective of this study has been to counter some of the oversimplifications and clarify some of the contradictions prevalent in much of the thinking on the organization of private and public secondary schools in the United States. My aim has been to offer a more elaborated view of the extent of organizational control in schools - how it is distributed across actors and to what degree it varies across different kinds of schools. Such clarification is necessary because of the crucial importance of the organizational structure of schools to the performance and well-being of teachers and students, a conclusion increasingly accepted by many in the realms of both research and policy in éducation.

Presently we need a more detailed and refined investigation into the nature of organizational control in schools, one that asks: By what forms and mechanisms is teachers' work controlled? How does this control vary across different organizational issues and in different kinds of school settings? Beyond establishing the degree and forms of control, future research must then turn to the larger question of the consequences of control. What impact does the distribution of control have on how schools function? In what ways do the degrees and forms of organizational control in schools affect the lives and behaviors of students and teachers within them?

If schools are to be improved, teaching must be improved. But in order to improve teaching, we must first better understand how the work of teachers is currently organized and with what consequences.

\section{References}

Anderson, C. (1982). The search for school climate: A review of the research. Review of Educational Research, 52, 368-420.

Apple, M. (1982). Education and power. Boston: Routledge \& Kegan Paul.

Bacharach, S. (1990). Education reform: Making sense of it all. Boston: Allyn \& Bacon.

Bacharach, S., Bauer, S., \& Shedd, J. (1988). The learning workplace: The conditions and resources of teaching. In National Education Association (Ed.), Conditions and resources of teaching (pp. 8-40). Washington, DC: National Education Association. 
Bidwell, C. (1965). The school as a formal organization. In J. March (Ed.), Handbook of organizations (pp. 973-1002). Chicago: Rand McNally.

Bidwell, C., \& Kasarda, J. (1980). Conceptualizing and measuring the effects of school and schooling. American Journal of Education, 89, 401-431.

Borman, K, \& Spring, J. (1984). Schools in central cities. New York: Longman.

Bourdieu, P., \& Passeron, J-C. (1977). Reproduction: In education, society and culture. Beverly Hills, CA: Sage.

Bowles, S., \& Gintis, H. (1976). Schooling in capitalist America. New York: Basic Books.

Bryk, A., Lee, V., \& Smith, J. (1990). High school organization and its effects on teachers and students: An interpretive summary of the research. In W. H. Clune \& J. F. Witte (Eds.), Choice and control in American education: Vol. 1. The theory of choice and control in education. New York: Falmer Press.

Bryk, A., \& Raudenbush, S. (1992). Hierarchical linear models for social and behavioral research. Newbury Park: Sage.

Carnegie Forum on Education and the Economy. (1986). A nation prepared: Teachers for the 21st century. New York: Author.

Choy, S., Medrich, E., Henke, R., \& Bobbitt, S. (1992). Schools and staffing in the U.S.: A statistical profile, 1987-88. Washington, DC: National Center for Education Statistics.

Chubb, J. E., \& Moe; T. (1990). Politics, markets and America's schools. Washington, DC: Brookings Institution.

Clune, W. H., \& Witte, J. F. (Eds.). (1990). Choice and control in American education: Vol. 1. The theory of choice and control in education. New York: Falmer Press.

Cohen, M., March, J., \& Olsen, J. (1972). A garbage can theory of organizational decision making. Administrative Science Quarterly, 17, 1-25.

Coleman, J., \& Hoffer, T. (1987). Public and private schools: The impact of communities. New York: Basic Books.

Conley, S. (1991). Review of research on teacher participation in school decision making. In G. Grant (Ed.), Review of research in education (pp. 225-266). Washington, DC: American Educational Research Association.

Conley, S., \& Cooper, B. (1991). The school as a work environment: Implications for reform. Boston: Allyn \& Bacon.

Corcoran, T., Walker, L., \& White, J. L. (1988). Working in urban schools. Washington, DC: Institute for Educational Leadership.

David, J. (1989). Synthesis of research on school-based management. Educational Leadership, $46(8), 45-52$.

Dewey, J. (1974). The child and the curriculum. Chicago: University of Chicago Press. (Original work published 1902)

Dreeben, R. (1968). On what is learned in school. Reading, MA: Addison-Wesley.

Dreeben, R. (1973). The school as a workplace. In R. W. Travers (Ed.), Second handbook of research on teaching (pp. 450-473). Chicago: Rand McNally.

Durkheim, E. (1961). Moral education: A study in the theory and application of the sociology of education (Trans. by E. K. Wilson \& H. Schnurer). New York: Free Press. (Original work published 1925)

Fantini, M., Gittell, M., \& Magat, R. (1979). Community control and the urban school. New York: Praeger.

Firestone, W. (1985). The study of loose coupling: Problems, progress, and prospects. In A. Kerckhoff (Ed.), Research in the sociology of education and socialization (vol. 5, pp. 3-30). Greenwich, CT: JAI Press.

Friedson, E. (1973). The professions and their prospects. Beverly Hills, CA: Sage.

Friedson, E. (1984). The changing nature of professional control. Annual Review of Sociology, $10,1-20$.

Giroux, H. (1982). Ideology, culture and the process of schooling. Philadelphia: Temple University Press. 
Goodlad, J. (1985). Structure, process and an agenda. In K. Rehage (Ed.), The ecology of school renewal (pp. 1-19). Chicago: University of Chicago Press.

Grant, G. (1988). The world we created at Hamilton High. Cambridge, MA: Harvard University Press.

Henry, J. (1965). Culture against man. New York: Vintage.

Holmes Group. (1986). Tomorrow's teachers. East Lansing, MI: Author.

Ingersoll, R. (1993). Loosely coupled organizations revisited. Research in the Sociology of Organizations, 11, 81-112.

Ingersoll, R. (forthcoming). Conflict and control in American schools: Teachers' work and the structure of educational organizations. Princeton, NJ: Princeton University Press.

Jackson, P. (1968). Life in classrooms. New York: Holt, Rinehart, \& Winston.

Johnson, S. M. (1990). Teachers at work. New York: Basic Books.

Katz, M. (1972). Class, bureaucracy and schools. New York: Vintage.

Kaufman, S. (1991). 1988 schools and staffing survey sample design and estimation. Washington, DC: National Center for Education Statistics.

Kirst, M. (1989). Who should control the schools. In T. J. Sergiovanni \& J. Moore (Eds.), Schooling for tomorrow (pp. 62-88). Boston: Allyn \& Bacon.

Kozol, J. (1967). Death at an early age. Boston: Houghton-Mifflin.

Lee, V., Dedrick, R., \& Smith, J. (1991). The effect of the social organization of schools on teachers' efficacy and satisfaction. Sociology of Education, 64, 190-208.

Lortie, D. (1969). The balance of control and autonomy in elementary school teaching. In A. Etzioni (Ed.), The semi-professions and their organizations: Teachers, nurses and social workers (pp. 1-53). New York: Free Press.

Lortie, D. (1975). School teacher. Chicago: University of Chicago Press.

March, J., \& Olsen, J. (1976). Ambiguity and choice in organizations. Bergen, Norway: Universitetsforlaget.

Meyer, J., \& Scott, W. R. (1983). Organizational environments: Ritual and rationality. Beverly Hills, CA: Sage.

National Commission on Excellence in Education. (1983). A nation at risk: The imperative for educational reform. Washington, DC: Government Printing Office.

Pallas, A. (1988). School climate in American high schools. Teachers College Record, 89, 541-543.

Parsons, T. (1959). The school class as a social system: Some of its functions in American society. Harvard Educational Review, 29, 297-318.

Pfeffer, J. (1981). Power in organizations. Marshfield, MA: Pitman.

Pfeffer, J. (1982). Organizations and organization theory. Marshfield, MA: Pitman.

Ravitch, D. (1974). The great school wars. New York: Harper.

Rogers, D. (1968). 110 Livingston Street. New York: Vintage.

Rosenholtz, S. (1989). Teacher's workplace: The social organization of schools. New York: Longman.

Rowan, B. (1990). Commitment and control: Alternative strategies for the organizational design of schools. In C. Cazden (Ed.), Review of research in education (vol. 16, pp. 353389). Washington, DC: American Educational Research Association.

Rowan, B., Raudenbush, S., \& Kang, S. J. (1991). Organizational design in high schools: A multilevel analysis. American Journal of Education, 99, 238-260.

Sergiovanni, T. J., \& Moore, J. (1989). Schooling for tomorrow. Boston: Allyn \& Bacon.

Shedd, J., \& Bacharach, S. (1991). Tangled hierarchies. San Francisco: Jossey-Bass.

Sorokin, P. (1927). Social and cultural mobility. New York: Harper \& Row.

Stevenson, D., \& Baker, D. (1991). State control of the curriculum and classroom instruction. Sociology of Education, 64, 1-10.

Tyler, W. (1988). School organization. New York: Croom Helm.

Waller, W. (1932). The sociology of teaching. New York: Wiley. 
Weick, K (1976). Educational organizations as loosely coupled systems. Administrative Science Quarterly, 21, 1-19.

Weick, K (1984). Management of organizational change among loosely coupled elements. In P. Goodman (Ed.), Change in organizations (Pp. 375-409). San Francisco: Jossey-Bass.

Weis, L., Altbach, P., Kelly, G., Petrie, H., \& Slaughter, S. (1989). Crisis in teaching. Albany: State University of New York Press.

Wise, A. (1979). Legislated learning: The bureaucratization of the American classroom. Berkeley: University of California Press.

Support for this project was provided through a Research Fellowship jointly sponsored by the National Science Foundation and the National Center for Education Statistics, and administered by the American Educational Research Association. A previous version of this article was presented at the Annual Meeting of the American Sociological Association
in August 1993 . 